\title{
Ionic Composition of Endolymph and Perilymph in the Inner Ear of the Oyster Toadfish, Opsanus tau
}

\author{
TAMER A. GHANEM ${ }^{1, *}$ KATHRYN D. BRENEMAN ${ }^{1}$, RICHARD D. RABBITT ${ }^{1,2,} \dagger$ \\ AND H. MACK BROWN ${ }^{3}$ \\ ${ }^{1}$ Department of Bioengineering, University of Utah, Salt Lake City, Utah 84112; ${ }^{2}$ Marine Biological \\ Laboratory, Woods Hole, Massachusetts 02543; and ${ }^{3}$ Dept. of Physiology, University of Utah,
}

Salt Lake City, Utah 84112

\begin{abstract}
The concentrations of free $\mathrm{Na}^{+}, \mathrm{K}^{+}, \mathrm{Ca}^{2+}$, and $\mathrm{Cl}^{-}$in endolymph and perilymph from the inner ear of the oyster toadfish, Opsanus tau, were measured in vivo using double-barreled ion-selective electrodes. Perilymph concentrations were similar to those measured in other species, while endolymph concentrations were similar to those measured previously in elasmobranch fish, though significantly different from concentrations reported in mammals. Perilymph concentrations (mean \pm std. dev.) were as follows: $\mathrm{Na}^{+}, 129 \mathrm{mmol} \mathrm{l}^{-1} \pm 20 ; \mathrm{K}^{+}, 4.96 \mathrm{mmol} \mathrm{l} l^{-1} \pm 2.67 ; \mathrm{Ca}^{2+}$, $1.83 \mathrm{mmol} \mathrm{l}^{-1} \pm 0.27$; and $\mathrm{Cl}^{-}, 171 \mathrm{mmol} \mathrm{l}^{-1} \pm 20$. Saccular endolymph concentrations were $\mathrm{Na}^{+}, 166 \mathrm{mmol} \mathrm{l}^{-1} \pm 22$; $\mathrm{K}^{+}, 51.4 \mathrm{mmol} \mathrm{l}^{-1} \pm 16.7 ; \mathrm{Ca}^{2+}, 2.88 \mathrm{mmol} \mathrm{l}^{-1} \pm 0.27$; and $\mathrm{Cl}^{-}, 170 \mathrm{mmol} \mathrm{l}^{-1} \pm 12$; and semicircular canal (utricular vestibule) endolymph concentrations were $\mathrm{Na}^{+}, 122 \mathrm{mmol}$ $\mathrm{l}^{-1} \pm 15 ; \mathrm{K}^{+}, 47.7 \mathrm{mmol} \mathrm{l}^{-1} \pm 13.2 ; \mathrm{Ca}^{2+}, 1.78 \mathrm{mmol} \mathrm{l}^{-1} \pm$ $0.48 ; \mathrm{Cl}^{-}, 176 \mathrm{mmol} \mathrm{l}^{-1} \pm 27$. The relatively high concentrations of $\mathrm{Ca}^{2+}$ and $\mathrm{Na}^{+}$in the endolymph may have significant implications for the physiological function of the mechanoelectrical transduction channels in the vestibular hair cells of fish compared to those of their mammalian counterparts.
\end{abstract}

\section{Introduction}

Mechanoelectrical transduction (MET) of sound and motion by the inner ear is highly dependent on the ionic composition of the fluids bathing the auditory and vestibular

Received 12 May 2007; accepted 3 October 2007.

* Current Address: University of Virginia, Charlottesville, VA 22908.

$\dagger$ To whom correspondence should be addressed. E-mail: r.rabbitt@utah.edu

Abbreviations: AE, artificial endolymph; AP, artificial perilymph; MET, mechanoelectrical transduction. hair cells (Tasaki and Fernandez, 1952; Smith et al., 1954; Corey and Hudspeth, 1979; Crawford and Fettiplace, 1983; Marcus et al., 1983). Much like the epithelial cells of the renal tubules, bladder, and sweat glands, the sensory hair cells of the inner ear are juxtaposed between two different fluids: endolymph, an unusual extracellular fluid, has high $\mathrm{K}^{+}$and low $\mathrm{Na}^{+}$concentrations in mammals and bathes the apical surface of the hair cells; perilymph, resembling cerebrospinal fluid, bathes the basolateral surfaces. The unique ionic composition of endolymph is thought to be maintained by the stria marginal cells and vestibular dark cells in mammals (Marcus and Marcus, 1987; Marcus and Shen, 1994; Wangemann, 1995) and ionocytes in fish (Mayer-Gostan et al., 1997). The electrochemical gradient between the two major extracellular compartments and the intracellular space drives ionic current flow through the various ion channels in sensory hair cells and is fundamental for the function of the inner ear organs.

The importance of the ionic composition of perilymph and endolymph in hair-cell physiology has motivated several previous studies in a variety of species including fish (Enger, 1964; Rüsch and Thurm, 1989; Crawford et al., 1991), amphibians (Corey and Hudspeth, 1983b), and reptiles and mammals (Citron et al., 1956; Maggio, 1966a; Silverstein and Schuknecht, 1966; Bosher and Warren, 1968, 1978; Davies, 1968; Makimoto and Silverstein, 1974; Couloigner et al., 1999; Sauer et al., 1999). Ions mediate a number of processes in hair cells, including mechanical hair bundle movements (Ricci and Fettiplace, 1998), fast and slow adaptation of MET currents (Ricci et al., 1998; Wu et al., 1999; Eatock, 2000; Hudspeth, 2005), and hair-cell electrical resonance (Art et al., 1987; Steinacker, 1996; Ricci and Fettiplace, 1998; Armstrong and Roberts, 2001). 
The mechanotransducer has a nonspecific cation conductance with a large sodium, potassium, and calcium permeability (Ohmori, 1985). The rate of adaptation of the transduction current to step hair bundle displacements is exquisitely sensitive to endolymph calcium concentration (Ricci and Fettiplace, 1998; Ricci et al., 2005). It has also been suggested that the hair-cell resting potential, regulated in part by calcium-dependent adaptation, may provide the depolarizing current necessary for the sharpest tuning, greatest sensitivity, and most linear response (Farris et al., 2006). It is therefore important to know the specific physiological concentrations on an organ- and animal-specific basis when studying hair cell physiology or comparing species.

In the present work we report in vivo concentrations of $\mathrm{Ca}^{2+}, \mathrm{Cl}^{-}, \mathrm{K}^{+}$, and $\mathrm{Na}^{+}$in the inner ear fluids and blood plasma of the oyster toadfish, Opsanus tau Linnaeus. This species is well established as an animal model for the study of vestibular end-organ physiology (Boyle and Highstein, 1990a, b; Boyle et al., 1991; Rabbitt et al., 1994, 1999; Highstein et al., 1996; Ghanem et al., 1998; Ghanem, 2002). Ion-selective microelectrodes were the logical choice for the in vivo measurements due to the limited access and relatively small volumes of inner ear fluids. The techniques and theory behind ion-selective electrodes will not be included here; the interested reader is referred to books and reviews on this subject (Koryta, 1972, 1977, 1984, 1986, 1988, 1990; Thomas, 1978; Covington, 1979; Ammann, 1986). The ionic composition of the toadfish inner ear fluids has not been previously reported.

\section{Materials and Methods}

\section{Ion-selective electrodes}

Double-barreled microelectrodes were prepared from borosilicate glass (Warner Instrument Corporation, OD 1.5 $\mathrm{mm}$, ID $0.86 \mathrm{~mm}$ ), with one barrel containing a filament and the other without. Electrodes were silanized in batches of five by selectively exposing the ion-selective barrel to saturated trimethylchlorosilane (Pierce, Rockford, IL) vapor at room temperature for $1 \mathrm{~min}$ and baking them in a $250{ }^{\circ} \mathrm{C}$ oven for $1 \mathrm{~h}$. Double-barreled pipettes were pulled on a model 700C vertical pipette puller (David Kopf, Tujunga, CA) using a two-step pulling procedure. This typically yielded electrodes with tip diameters of 1.5-2.5 $\mu \mathrm{m}$.

An ionophore cocktail, noted below for each ion, was loaded into the sensor barrel using a back-filling procedure (Thomas, 1978). A small amount of cocktail was injected into the shoulder of the ion-selective barrel using 50- $\mu$ l syringe with an attached 10-cm-long, 35 gauge stainless steel tube (Small Parts Inc., Miami Lakes, FL). A cat whisker was introduced into the shank of the ion-selective barrel to wick the cocktail to the tip of the microelectrode. Heights obtained using the above procedure were in the range of 1.0 to $1.5 \mathrm{~mm}$. Each barrel of the double-barreled microelectrode was filled with an appropriate reference solution. $\mathrm{Ag} / \mathrm{AgCl}$ wires were inserted into the two barrels, and silicone (Perfecto Manufacturing, Noblesville, IN) was applied at the insertion point to prevent evaporation and seal the electrode wires into each barrel of the pipette.

Calcium-selective electrodes were based on ionophore I-Cocktail A (Fluka Chemika, Ronkonkoma, NY), composed of $10.00 \mathrm{wt} \%$ calcium ionophore I (ETH 1001), 89.00 wt \% 2-nitrophenyl octyl ether, and $1.00 \mathrm{wt} \%$ sodium tetraphenylborate. The internal filling solution for these electrodes was $10 \mathrm{mmol} \mathrm{l}^{-1} \mathrm{CaCl}_{2}$, and the reference barrel was filled with $150 \mathrm{mmol} \mathrm{l}^{-1} \mathrm{KCl}$. Electrodes were preconditioned overnight in a $100 \mathrm{mmol} \mathrm{l}^{-1} \mathrm{CaCl} 2$ solution.

Chloride-selective electrodes were based on the ion-exchanger methyltricapryl ammonium ion (Corning \#477315, Midland, MI) dissolved in 1-decanol (ion-exchanger courtesy of Dr. Brown, University of Utah, Salt Lake City, UT). The internal filling solution for these electrodes consisted of $150 \mathrm{mmol} \mathrm{l}^{-1} \mathrm{KCl}$, and the reference barrel was filled with $200 \mathrm{mmol} \mathrm{l}^{-1} \mathrm{MgSO}_{4}$. Electrodes were preconditioned overnight in a $100 \mathrm{mmol} \mathrm{l}^{-1} \mathrm{NaCl}$ solution.

Potassium-selective electrodes were based on the ionexchanger $\mathrm{K}^{+}$tetrakis ( $p$-chlorophenyl) borate (Corning \#477317, Midland, MI) dissolved in 2-3-dimethyl-nitrobenzene (ion-exchanger courtesy of Dr. Brown, University of Utah, Salt Lake City, UT). The internal filling solution for these electrodes consisted of $100 \mathrm{mmol} \mathrm{l}^{-1} \mathrm{KCl}$, and the reference barrel was filled with $150 \mathrm{mmol}^{-1} \mathrm{NaCl}$. Electrodes were preconditioned overnight in a $125 \mathrm{mmol} \mathrm{l}^{-1} \mathrm{KCl}$ solution.

Sodium-selective electrodes were based on ionophore III (ETH 2120) (Fluka Chemika, Ronkonkoma, NY). The following cocktail was prepared: $10.00 \mathrm{wt} \%$ sodium ionophore III, 89.5 wt\% 2-nitrophenyl octyl ether (Fluka Chemika, Ronkonkoma, NY), 0.5 wt\% sodium tetraphenyl borate (Fluka Chemika, Ronkonkoma, NY). Electrodes were preconditioned overnight in a $100 \mathrm{mmol} \mathrm{l}^{-1} \mathrm{NaCl}$ solution.

\section{Calibration}

All cation electrodes were characterized in three different sets of solutions: a set of serially diluted solutions containing only the ion of interest (Pure), a set of artificial endolymph solutions (AE), and a set of artificial perilymph solutions (AP). Both AE and AP solution sets were designed to span the range of previously published data for perilymph and endolymph (Peterson, 1978; Corey and Hudspeth, 1983b; Ikeda et al., 1988; Rüsch and Thurm, 1989). The chloride electrode was calibrated in two sets of serially diluted $\mathrm{NaCl}$ and $\mathrm{KCl}$ solutions. The compositions for all calibration solutions are summarized in Table 1.

Electrodes were calibrated just prior to and immediately after in vivo measurements. For each of the different ions 
Table 1

Concentrations (mmol $\mathrm{l}^{-1}$ ) of ions in calibration standard solutions

\begin{tabular}{|c|c|c|c|}
\hline Ion & Pure & $\mathrm{AE}$ & AP \\
\hline $\mathrm{K}^{+}$ & $0.920-250$ & $\begin{array}{l}26.0-200 \\
\left(\mathrm{Na}^{+}: 100\right) \\
\left(\mathrm{Ca}^{2+}: 1.00\right) \\
\left(\mathrm{Mg}^{2+}: 1.00\right)\end{array}$ & $\begin{array}{l}0.780-10.0 \\
\left(\mathrm{Na}^{+}: 170\right) \\
\left(\mathrm{Ca}^{2+}: 3.00\right) \\
\left(\mathrm{Mg}^{2+}: 1.00\right)\end{array}$ \\
\hline $\mathrm{Na}^{+}$ & $0.920-250$ & $\begin{array}{l}3.00-253 \\
\left(\mathrm{Ca}^{2+}: 1.00\right) \\
\left(\mathrm{K}^{+}: 130\right) \\
\left(\mathrm{Mg}^{2+}: 1.00\right)\end{array}$ & $\begin{array}{l}102-250 \\
\left(\mathrm{Ca}^{2+}: 3.00\right) \\
\left(\mathrm{K}^{+}: 3.00\right) \\
\left(\mathrm{Mg}^{2+}: 1.00\right)\end{array}$ \\
\hline $\mathrm{Ca}^{2+}$ & $0.080-10.0$ & $\begin{array}{l}0.260-5.00 \\
\left(\mathrm{~K}^{+}: 130\right) \\
(\mathrm{Na}: 100) \\
\left(\mathrm{Mg}^{2+}: 1.00\right)\end{array}$ & $\begin{array}{l}0.780-10.0 \\
\left(\mathrm{~K}^{+}: 3.00\right) \\
(\mathrm{Na}: 170) \\
\left(\mathrm{Mg}^{2+}: 1.00\right)\end{array}$ \\
\hline $\mathrm{Cl}^{-}$ & $0.920-250$ & - & - \\
\hline
\end{tabular}

The range of ionic compositions is shown for pure (single ion) solution, artificial endolymph (AE) solution, and artificial perilymph (AP) solution. The quantities in parenthesis are the constant ion background levels.

measured, three electrodes were prepared a day in advance of the experiment. Following overnight preconditioning, the electrodes were calibrated in the pure solution set. The electrode exhibiting the most ideal "Nernstian" response was selected for further calibration in the other two sets of solutions (AP and AE). The chloride electrode was calibrated in two sets of solutions, pure $\mathrm{NaCl}$ and $\mathrm{KCl}$, instead of the AP and AE. In all calibrations, electrodes were inserted in the lowest concentration solution first, followed by progressively higher concentration solutions to prevent cross-contaminating the calibration standards.

\section{Instrumentation}

The experimental setup was designed using high-impedance-potential measurements since the electrodes themselves exhibited a resistance of $10^{10}-10^{11} \Omega$. All ion measurements, whether in vivo or standard calibrations, were performed in a Faraday cage. A custom-built dual-channel differential amplifier, based on an ultra-high-input impedance $\left(10^{15} \Omega\right)$ instrumentation amplifier (INA116, BurrBrown, Tucson, AZ), was placed close to the measurement electrode. The common mode rejection ratio was $80 \mathrm{~dB}$ at a gain of 2.0, and the input bias current was $<4.0 \mathrm{fA}$. Both the negative and positive inputs of the amplifier were connected to the $\mathrm{Ag} / \mathrm{AgCl}$ wires from the reference barrel and the ion-sensitive barrel, respectively. The negative input was grounded with respect to amplifier ground. The differential output from the instrumentation amplifier was connected to a digital voltmeter (DM5520, Tektronix, Beaverton, OR) and interfaced (IEEE 488, GPIB, National Instruments, Austin, TX) to a personal computer for data acquisition and analysis.

\section{In vivo measurements}

Ion measurements were made in adult toadfish $(n=10)$, supplied by the Marine Biological Laboratory (Woods Hole, MA), using surgical methods described previously (Boyle and Highstein, 1990a, b). Surgical procedures utilized in this study were approved by the University of Utah's Animal Care and Use Committee. The fish were anesthetized by immersion in $5 \mathrm{mg} / \mathrm{l}$ of 3-aminobenzoic acid ethyl ester (MS222, Sigma, St. Louis, MO) and tail immobilized with an intramuscular injection of $0.05 \mathrm{mg} / \mathrm{kg}$ pancuronium bromide (Sigma, St. Louis, MO). During surgery, the fish was secured in an acrylic plastic tank containing seawater, which covered about two-thirds of the body. The non-immersed regions of the body were covered with moist tissues. A 5-mm-diameter hole was made in the cranium, lateral to the dorsal course of the anterior canal and rostral to the common crus. Access to perilymph was obtained by opening the skull in a position just lateral to the anterior canal and cutting a fistula in the perilymphatic sac.

Bilateral measurements were made and were completed in less than $60 \mathrm{~min}$. Each electrode was recalibrated in two standard solutions to test for any potential drift just prior to insertion into the inner ear fluid. The electrode was recalibrated or discarded as needed. The fish was grounded with respect to amplifier ground. Measurements were performed by lowering the double-barreled ion-selective electrode into the fistula of the perilymphatic sac, using a micromanipulator under visual guidance (OPNI 1, Carl Zeiss, Thornwood, NY). Measurement for each ion required 6 min (at least five time constants of the slowest observed electrode response). After each measurement, a two-point calibration in the relevant (endolymph or perilymph) artificial solution was performed, and the slope and $y$-intercept for the calibration were compared to the electrode calibration done prior to the in vivo measurement. Data were discarded if electrode drift occurred.

Upon completion of bilateral ion measurements in perilymph, further surgery was performed to access the utricular and saccular vestibules. The overlying cartilage and membranes were removed to expose the horizontal and anterior ampullae and a portion of the utricle. The perilymph in the cavity was replaced with fluorocarbon (FC-75, 3-M Corp.) to isolate the endolymph-filled utricle and saccule. A tungsten wire attached to an electrosurgical generator (Valleylab, SSE4, Boulder, CO) was lowered through the fluorocarbon to contact the utricular or saccular membrane. A brief 8 -W cutting waveform was then applied to form a fistula in the utricular membranous labyrinth or saccular membrane. Fluorocarbon was applied to cover the fistula and, because it is immiscible with endolymph, served as a barrier to prevent evaporation of endolymph and sample contamination by perilymph. It is important to note that the pressure required to overcome the fluorocarbon/water inter- 
face surface tension $(\sim 0.015 \mathrm{~N} / \mathrm{m})$ and push endolymph though a $50-\mu \mathrm{m}$-diameter fenestration in the membranous labyrinth is about $600 \mathrm{~Pa}-\mathrm{a}$ value that far exceeds the endolymph pressure in vivo and thus prevented any fluid flow or ion contamination. The fluorocarbon also prevented dehydration during the experimental procedure.

Ions were measured in the plasma of eight oyster toadfish to establish a baseline to compare with endolymph and perilymph concentrations. The plasma was obtained after completing the inner ear measurements by withdrawing 1.5 $\mathrm{ml}$ of blood from the conus of the heart. The blood sample was placed into a 2-ml Eppendorf tube and spun to separate the plasma from the cells. The plasma was analyzed utilizing ion-selective electrodes and photochemical techniques by a commercial laboratory (Analytics Incorporated, Gaithersburg, MD).

\section{Results}

Typical calibration curves for all electrodes, $\mathrm{K}^{+}, \mathrm{Na}^{+}$, $\mathrm{Ca}^{2+}, \mathrm{Cl}^{-}$, are provided in Figure 1. For simplicity, data are presented in terms of concentrations rather than activities. The error bars denote the $95 \%$ confidence intervals of the log-linear fit based on a two-tailed Student's $t$-test. $\mathrm{K}^{+}$ calibration in AE (Fig. 1, slope $=51.9 \mathrm{mV} /$ decade concentration change) exhibited more "Nernstian" behavior than in AP solution (slope $=33.6 \mathrm{mV} /$ decade). This is likely due to fewer interfering ions in the potassium AE solution than in the AP solution. Sodium electrodes showed similar behavior in AP solution (Fig. 1B, slope $=49.6 \mathrm{mV} /$ decade) and pure solution (slope $=49.4 \mathrm{mV} /$ decade), but the slope declined in the $\mathrm{AE}$ solution due to interfering potassium (slope $=35.8 \mathrm{mV} /$ decade concentration change). Sodium electrodes were not sensitive below $6 \mathrm{mmol} \mathrm{l}^{-1}$. Calcium electrodes were also solution-dependent (Fig. 1C): pure, $22.7 \mathrm{mV} /$ decade; AP, $24.4 \mathrm{mV} /$ decade; AE, $35.1 \mathrm{mV} / \mathrm{de}-$ cade. The chloride-electrode series was calibated (Fig. 1D) in pure $\mathrm{NaCl}$ (slope $=-44.6 \mathrm{mV} /$ decade) and $\mathrm{KCl}$ (slope $=$ $-47.8 \mathrm{mV} /$ decade).

The perilymph and endolymph data are summarized in Table 2. Perilymph results are typical of extracellular fluid
A
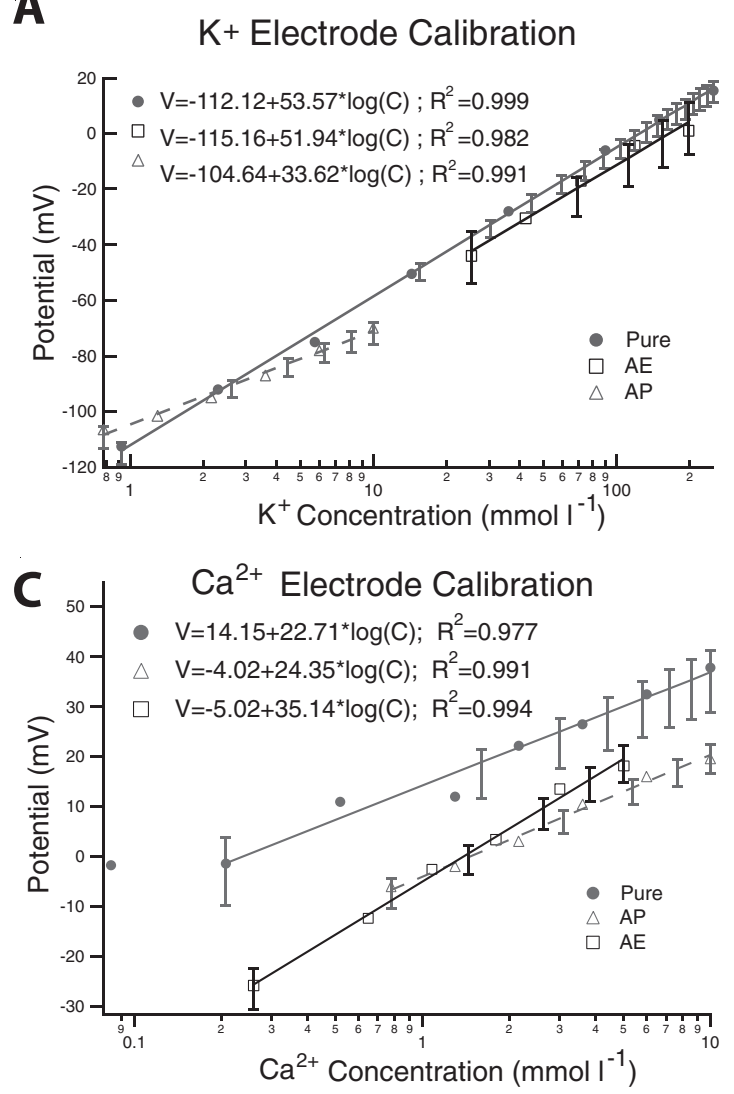

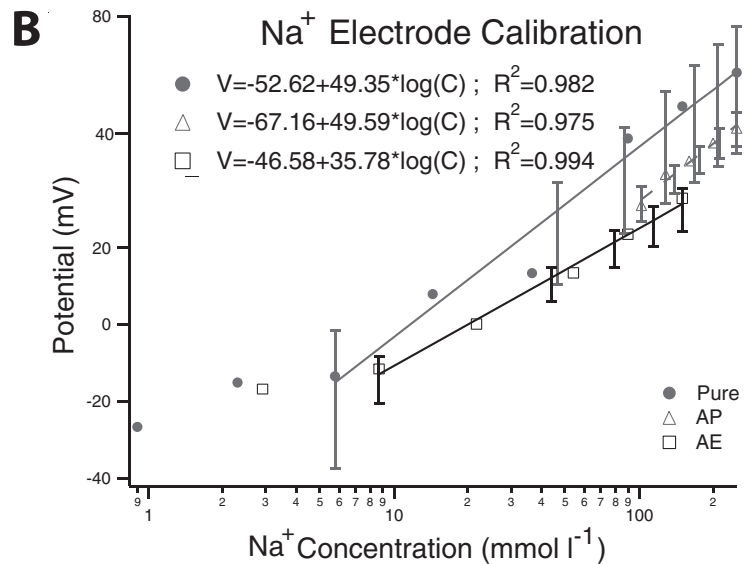

D

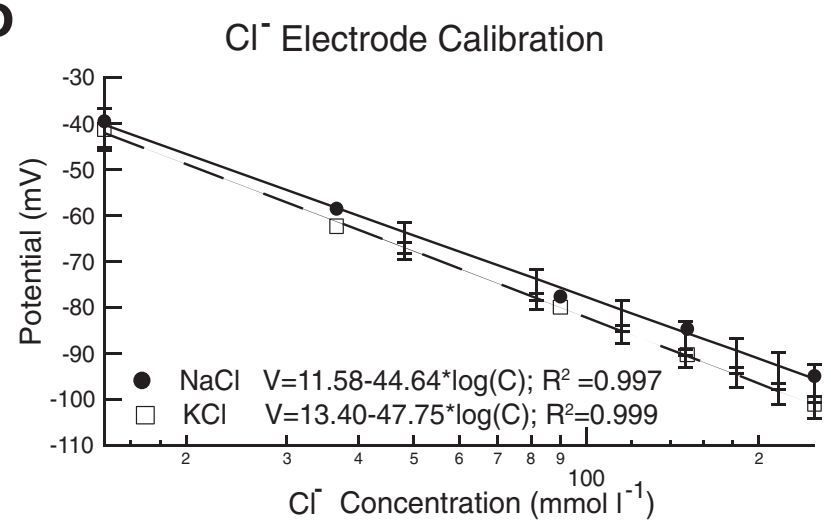

Figure 1. Calibration curves for the potassium (A), sodium (B), and calcium (C) ion-sensitive electrodes in pure, artifical endolymph (AE), and artificial perilymph (AP) solutions. The calibration curve for the chloride electrode (D) is shown in $\mathrm{NaCl}$ and $\mathrm{KCl}$ solutions. Refer to Table 1 for ion concentrations in each calibration solution. Error bars denote the $95 \%$ confidence interval based on a 2-tailed Student's $t$-test. A linear fit for the electrode potential $v s$. ion concentration and the corresponding $R$-squared value are shown. 
Table 2

Concentrations $\left(\mathrm{mmol} \mathrm{l}^{-1}\right)$ of ions in endolymph and perilymph

\begin{tabular}{lcccc}
\hline \hline \multicolumn{1}{c}{ Fluid } & $\mathrm{Ca}^{2+}$ & $\mathrm{Cl}^{-}$ & $\mathrm{K}^{+}$ & $\mathrm{Na}^{+}$ \\
\hline $\begin{array}{c}\text { Utricle } \\
\text { Endolymph }\end{array}$ & $\begin{array}{c}1.78 \pm 0.48 \\
(n=4)\end{array}$ & $\begin{array}{c}176 \pm 27 \\
(n=6)\end{array}$ & $\begin{array}{c}47.7 \pm 13.2 \\
(n=7)\end{array}$ & $\begin{array}{c}122 \pm 15 \\
(n=6)\end{array}$ \\
$\begin{array}{c}\text { Saccule } \\
\text { Endolymph }\end{array}$ & $\begin{array}{c}n=88 \pm 0.27 \\
(n=3)\end{array}$ & $\begin{array}{c}170 \pm 12 \\
(n=5)\end{array}$ & $\begin{array}{c}51.4 \pm 16.7 \\
(n=6)\end{array}$ & $\begin{array}{c}166 \pm 22 \\
(n=4)\end{array}$ \\
Perilymph & $\begin{array}{c}1.83 \pm 0.27 \\
(n=5)\end{array}$ & $\begin{array}{c}171 \pm 20 \\
(n=5)\end{array}$ & $\begin{array}{c}4.96 \pm 2.67 \\
(n=5)\end{array}$ & $\begin{array}{c}129 \pm 20 \\
(n=5)\end{array}$ \\
\hline
\end{tabular}

Results displayed as mean \pm standard deviation. The number of sample fish, $n$, is give in parenthesis below the measurement.

and of perilymph in other species. The predominant cation in toadfish perilymph was sodium (avg. $129 \mathrm{mmol}^{-1}, n=$ 5). Potassium (avg. $4.96 \mathrm{mmol}^{-1}, n=5$ ) and calcium (avg. $1.83 \mathrm{mmol}^{-1}, n=5$ ) concentrations were also typical for an extracellular fluid. The mean chloride concentration was larger than the combined mean cation concentrations (171 mmol $1^{-1}, n=5$ ), but the difference was not statistically significant.

Endolymph ionic concentrations were measured from two organs: the saccule and the utricular vestibule (semicircular canals). The predominant cation in toadfish saccular and utricular endolymph was sodium (avg. saccule $\left[\mathrm{Na}^{+}\right]=$ $166 \mathrm{mmol} \mathrm{l}^{-1}, n=4$; avg. utricle $\left.\left[\mathrm{Na}^{+}\right]=122, n=6\right)$. The $44 \mathrm{mmol} \mathrm{l}^{-1}$ difference between the saccule and utricle was statistically significant $(P=0.005$, two-tailed Student's $t$-test). The difference between the average calcium concentrations of the two fluids (saccule $\left[\mathrm{Ca}^{+}\right]=2.88 \mathrm{mmol} \mathrm{l}^{-1}$, $n=3$; utricle $\left[\mathrm{Ca} 2^{+}\right]=1.78, n=4$ ) was also statistically significant $(P=0.05)$. Differences between the average potassium (saccule $\left[\mathrm{K}^{+}\right]=51.4 \mathrm{mmol} \mathrm{l}^{-1}, n=6$; utricle $\left.\left[\mathrm{K}^{+}\right]=47.7 \mathrm{mmol} \mathrm{l}^{-1}, n=6\right)$ and the average chloride concentrations (saccule $\left[\mathrm{Cl}^{-}\right]=170 \mathrm{mmol} \mathrm{l}^{-1}, n=5$; utricle $\left.\left[\mathrm{Cl}^{-}\right]=176, n=6\right)$ were not statistically significant $(P>$ $0.5)$.

Results from blood plasma are summarized in Table 3. These results are very close to those previously published for this species (O'Neil, 1998) and to human plasma levels. Perilymph ion concentrations were very similar to plasma, with the exception of a higher chloride content. Both utricular and saccular endolymph potassium and chloride levels were significantly higher than plasma ion composition. As in other species, toadfish endolymph was hyperosmolar compared to plasma.

\section{Discussion}

The role of inner ear fluids in the transduction of sound and gravito-inertial acceleration is multi-faceted. The difference between the ionic composition of the inner ear fluid of fish and other species (Fig. 2) is significant and has physiological implications. Upon deflection of hair-cell stereocilia, mechanoelectrical transduction (MET) occurs as mechanically gated ion channels are opened, resulting in the influx of $\mathrm{K}^{+}, \mathrm{Na}^{+}$, and $\mathrm{Ca}^{2+}$ into hair cells (Assad et al., 1989; Ricci and Fettiplace, 1998; Fettiplace and Ricci, 2003). Perhaps most significant is the fact that the temporal responses of hair-cell MET currents are known to be sensitive to endolymph $\mathrm{Ca}^{2+}$ concentration, as manifested in MET adaptation kinetics displaying $\mathrm{Ca}^{2+}$-dependent components (Assad et al., 1989; Ricci and Fettiplace, 1998; Fettiplace and Ricci, 2003). In addition, hair-cell resonance, thought to keep the hair cell maximally sensitive over a specific and narrow frequency band, is mediated by basolateral voltage-gated $\mathrm{Ca}^{2+}$ channels and $\mathrm{Ca}^{2+}$-gated $\mathrm{K}^{+}$ channels and therefore would also be sensitive to the specific ionic milieu (Art et al., 1987; Ricci and Fettiplace, 1998; Armstrong and Roberts, 2001).

$\left[\mathrm{Ca}^{2+}\right]$ was found to be significantly higher in fish endolymph than in mammalian endolymph (Fig. 2). Indeed, $\left[\mathrm{Ca}^{2+}\right]$ in the endolymph was similar to that in blood plasma. Assuming that the transducer is conserved across species, one would expect higher input $\mathrm{Ca}^{2+}$ current in fish, and a corresponding increase in the rate of fast adaptation such that the MET current evoked by a step hair bundle displacement would quickly decrease to a fully adapted level (Ricci et al., 2005; Cheung and Corey, 2006). Two distinct phases of hair-cell adaptation have been described in hair cells from other organs and species: a fast component with a time constant of $0.3-5 \mathrm{~ms}$ and a slow component with a time constant of 10-100 ms (Fettiplace and Ricci, 2003). The kinetics of slow adaptation in turtle showed a significant dependence on calcium, with the time constant increasing from $1.8 \mathrm{~ms}$ in $2.8 \mathrm{mmol} \mathrm{l}^{-1} \mathrm{Ca}^{2+}$ to $3.6 \mathrm{~ms}$ in 0.05 mmol $1^{-1} \mathrm{Ca}^{2+}$ (Ricci et al., 2005). Though the time course of adaptation slowed down in lower $\mathrm{Ca}^{2+}$, the peak current increased (Ricci et al., 2005), consistent with earlier reports of a half-blocking dose of $1 \mathrm{mmol}^{-1}$ for the MET (Ricci and Fettiplace, 1998). If the fish mechanotransducer functions similarly to that of the turtle, at the $1-2 \mathrm{mmol} \mathrm{l}^{-1} \mathrm{Ca}^{2+}$ level reported here for the toadfish, fast MET adaptation might not be observable in vivo due to the long rise time and low frequencies associated with physiological vestibular stimuli. Furthermore, the dependence of slow adaptation kinetics on calcium level suggests that even slow adaptation

Table 3

Concentrations (mmol $\mathrm{l}^{-1}$ ) of ions in blood plasma

\begin{tabular}{lcrrrrrr}
\hline \hline & $\mathrm{Ca}^{2+}$ & $\mathrm{Cl}^{-}$ & $\mathrm{HCO}_{3}{ }^{-}$ & $\mathrm{K}^{+}$ & $\mathrm{Mg}^{2+}$ & $\mathrm{Na}^{+}$ & $\mathrm{PO}_{4}{ }^{3-}$ \\
\hline Average & 2.3 & 113 & 25.8 & 4.6 & 0.78 & 146 & 0.42 \\
Standard deviation & 0.1 & 2 & 5.1 & 0.3 & 0.08 & 1.2 & 0.07 \\
\# Sample fish & 9 & 9 & 9 & 9 & 9 & 9 & 9 \\
\hline
\end{tabular}



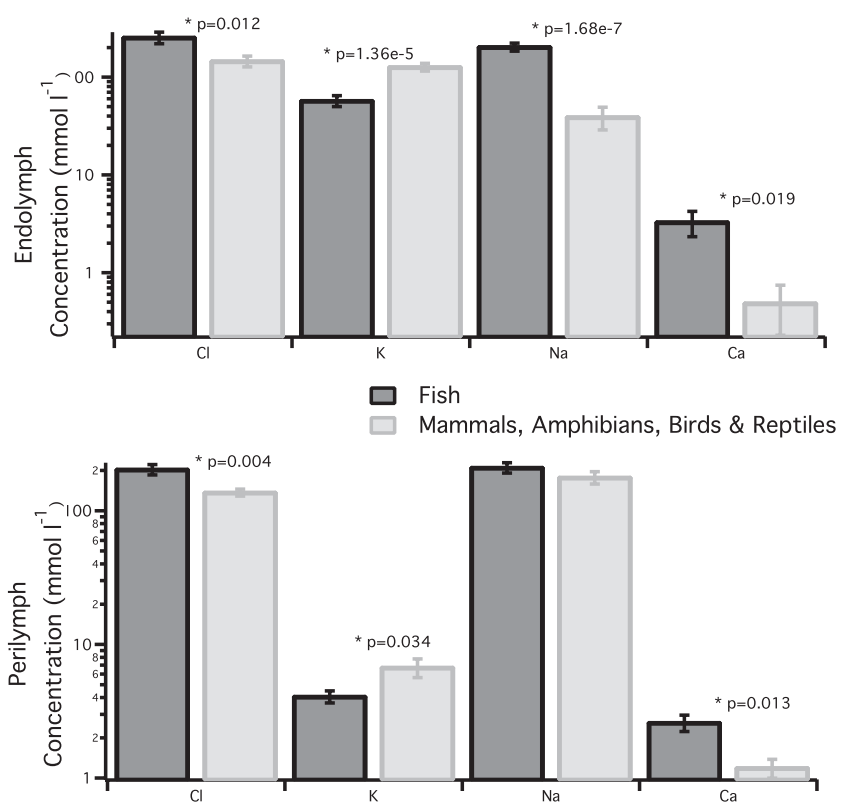

Figure 2. Comparison of composition of inner ear fluid for fish versus others (mammals, amphibians, and reptiles). Results are shown for endolymph (A) and perilymph (B) as the mean concentration $\left(\mathrm{mmol}^{-1}\right)$, with error bars denoting one standard error. The $P$ values calculated using a Student's $t$-test are also displayed to denote the significance of difference between sample populations. Fish data included endolymph and perilymph measurements, respectively, from Atlantic cod saccule and cranial cavity, basking shark saccule, canal, and cranial cavity, Cottus scorpius saccule and cranial cavity, Salmo irideus saccule and cranial cavity, skate saccule and cranial cavity (Enger, 1964); Atlantic cod canal and cranial cavity, burbot canal and cranial cavity, Greenland shark canal and bony labyrinth, rock grenedier canal and cranial cavity, grey sole canal (Fänge et al., 1972); shark canal (Garvin et al., 1988); skate canal and fenestra ovalis (Peterson, 1978); and toadfish utricle, saccule and perilymphatic cavity (present study). Other data included measurements from cat scala tympani and scala media, lizard scala vestibuli and scala media (Peterson, 1978); cat scala tympani and scala media, endolymphatic sac (Silverstein and Schuknecht, 1966); cat scala tympani and scala media, guinea pig scala tympani and utricle (Citron et al., 1956); cat scala tympani and utricle, dog scala tympani (Maggio, 1966b); cat scala tympani and scala media (Davies, 1968); cat scala vestibuli, scala tympani, scala media, and utricle (Makimoto and Silverstein, 1974); dog scala tympani and scala media, guinea pig scala tympani and scala media (Brusilow and Gordes, 1973); gerbil utricle and bony labyrinth (Marcus and Marcus, 1987); guinea pig scala tympani and utricle (Smith et al., 1954); guinea pig scala tympani and scala media (Johnstone et al., 1963); pigeon scala vestibuli and scala media (Sauer et al., 1999); rat scala vestubuli, scala tympani, and scala media (Bosher and Warren, 1968); bullfrog saccule (Corey and Hudspeth, 1983a); and turtle endolymphatic cochlea (Crawford et al., 1991).

may occur outside the range of naturally occurring head movements transduced by the vestibular end organs. This hypothesis is consistent with data collected in toadfish indicating that semicircular canal hair-cell MET currents and canal microphonics exhibit only very modest adaptation dynamics for physiological stimuli in vivo (Rabbitt et al., 2005), indicating that hair cells may be operating in a "fully-adapted" state. Thus, the semicircular canals in fish may provide an example in which high endolymph $\mathrm{Ca}^{2+}$ may function to tune the MET to achieve a broadband low-frequency sensitivity with limited adaptation to maintained hair-bundle displacements. An organism's ability to sense gravity and maintain its orientation within its terrestrial environment is of fundamental importance for its survival. Present results suggest the ionic composition of inner ear fluids may be tuned to facilitate this task.

Ionocytes have been found throughout the fish labyrinth (Mayer-Gostan et al., 1997) and have been specifically localized to the wall of the utricle and the common crus in the semicircular canals (Becerra and Anadon, 2003) and the wall of the saccule (Mayer-Gostan et al., 1997). These cells are thought to maintain the ionic gradient between endolymph, perilymph, and cranial fluid and are shown to contain large mitochondria and a membrano-tubular system in which $\mathrm{Na}^{+} / \mathrm{K}^{+}$-ATPase is located (Mayer-Gostan et al., 1997). Fish endolymph is typically higher in sodium than is mammalian endolymph, and cranial fluids are normally close in ionic composition to plasma (Mayer-Gostan et al., 1997). This study revealed a significant difference between fish and mammals in the $\mathrm{Na}^{+}$and $\mathrm{K}^{+}$gradients across the hair-cell epithelium and, consistent with previous studies, higher sodium levels in endolymph. These differences are likely due to differences in function between fish ionocytes and mammalian dark cells. Ion levels measured in the cranial fluid were similar to those of plasma.

The source of diversity in fluid ion concentrations between species and organs is currently unclear. The cellular machinery responsible for maintaining the ionic gradient between endolymph and perilymph differs between fish and mammals and, in the same animal, between organs (Marcus and Marcus, 1987; Marcus and Shen, 1994; Wangemann, 1995; Mayer-Gostan et al., 1997). The endolymphatic potential is generally positive with respect to the perilymph, though the difference varies between organs, ranging from $+80 \mathrm{mV}$ in the mammalian cochlea to $-10 \mathrm{mV}$ in fish semicircular canals (Mayer-Gostan et al., 1997; Rabbitt et al., 2005). This is not surprising given the inter-species variability in fluid ionic composition and regulatory mechanisms found throughout the inner ear (Salt and Thalmann, 1988). These differences encourage the measurement of ion concentrations of inner ear fluid in each organ for each animal species to properly interpret data from downstream MET events. Results from the present study demonstrate that the ionic composition of toadfish endolymph is significantly different from those measured in mammals, amphibians, and reptiles. These data combined with physiological response dynamics of afferents and hair cells suggest that endolymph concentrations may be uniquely regulated between different hair-cell organs to tune the frequency sensitivity and bandwidth to the needs of the animal. 


\section{Acknowledgments}

This work was supported by the National Institute of Deafness and Other Communications Disorders P01 DC01837, R01 DC06685, R01 DC04928, NASA NNA04CK67H, and NSF Igert DGE9987616. We thank S. M. Highstein and R. Boyle for their comments and suggestions.

\section{Literature Cited}

Ammann, D. 1986. Ion-Selective Microelectrodes. Principles, Design and Application. Springer-Verlag, New York.

Armstrong, C. E., and W. M. Roberts. 2001. Rapidly inactivating and non-inactivating calcium-activated potassium currents in frog saccular hair cells. J. Physiol. 536.1: 49-65.

Art, J. J., and R. Fettiplace. 1987. Variation of membrane properties in hair cells isolated from the turtle cochlea. J. Physiol. 385: 207-242.

Assad, J. A., N. Hacohen, and D. P. Corey. 1989. Voltage dependence of adaptation and active bundle movement in bullfrog saccular hair cells. Proc. Natl. Acad. Sci. USA 86: 2918-2922.

Becerra, M., and R. Anadon. 2003. Fine structure and development of ionocyte areas in the labyrinth of the trout (Salmo trutta fario). J. Anat. 183: 463-474.

Bosher, S. K., and R. L. Warren. 1968. Observations on the electrochemistry of the cochlear endolymph of the rat: a quantitative study of its electrical potential and ionic composition as determined by means of flame spectrophotometry. Proc. R. Soc. Lond. B Biol. Sci. 171: 227247 .

Bosher, S. K., and R. L. Warren. 1978. Very low calcium content of cochlear endolymph, an extracellular fluid. Nature 273: 377-378.

Boyle, R., and S. M. Highstein. 1990a. Efferent vestibular system in the toadfish: action upon horizontal semicircular canal afferents. J. Neurosci. 10: $1570-1582$.

Boyle, R., and S. M. Highstein. 1990b. Resting discharge and response dynamics of horizontal semicircular canal afferent of the toadfish, Opsanus tau. J. Neurosci. 10: 1557-1569.

Boyle, R., J. P. Carey, and S. M. Highstein. 1991. Morphological correlates of response dynamics and efferent stimulation in horizontal semicircular canal afferents of the toadfish, Opsanus tau. J Neurophysiol. 66: 1504-1521.

Brusilow, S., and E. Gordes. 1973. The mutual independence of the endolymphatic potential and the concentration of sodium and potassium in endolymph. J. Clin. Investig. 52: 2517-2521.

Cheung, E. L. M., and D. P. Corey. 2006. $\mathrm{Ca}^{2+}$ changes the force sensitivity of the hair-cell transduction channel. Biophys. J. 90: 124139.

Citron, L., D. Exley, and C. S. Hallpike. 1956. Formation, circulation and chemical properties of the labyrinthine fluids. Br. Med. Bull. 12: 101-104.

Corey, D. P., and A. J. Hudspeth. 1979. Response latency of vertebrate hair cells. Biophys. J. 26: 499-506.

Corey, D. P., and A. J. Hudspeth. 1983a. Analysis of the microphonic potential of the bullfrog's sacculus. J. Neurosci. 3: 942-961.

Corey, D. P., and A. J. Hudspeth. 1983b. Kinetics of the receptor current in bullfrog saccular hair cells. J. Neurosci. 3: 962-976.

Couloigner, V., M. Teixeira, O. Sterkers, and E. Ferrary. 1999. In vivo study of the electrochemical composition of luminal fluid in the guinea pig endolymphatic sac. Acta Oto-laryngol. 119: 200-202.

Covington, A. K. 1979. Ion-Selective Electrode Methodology. CRC Press, Boca Raton, FL.

Crawford, A. C., and R. Fettiplace. 1983. Auditory nerve responses to imposed displacements of the turtle basilar membrane. Hear. Res. 12: 199-208.

Crawford, A. C., M. G. Evans, and R. Fettiplace. 1991. The actions of calcium on the mechano-electrical transducer current of turtle hair cells. J. Physiol. 434: 369-398.

Davies, D. G. 1968. Biochemistry of the inner ear fluids-experimental and clinical observations. J. Laryngol. Otol. 82: 301-311.

Eatock, R. A. 2000. Adaptation in hair cells. Annu. Rev. Neurosci. 23: 285-314.

Enger, P. S. 1964. Ionic composition of the cranial and labyrinthine fluids and saccular D.C. potentials in fish. Comp. Biochem. Physiol. 11: $131-137$

Fänge, A., Å. Larsson, and U. Lidman. 1972. Fluids and jellies of the acusticolateralis system in relation to body fluids in Coryphaenoides rupestris and other fishes. Mar. Biol. 17: 180-185.

Farris, H. E., G. B. Wells, and A. J. Ricci. 2006. Steady-state adaptation of mechanotransduction modulates the resting potential of auditory hair cells, providing an assay for endolymph $\left[\mathrm{Ca}^{2+}\right]$. J. Neurosci. 26: $12526-12536$

Fettiplace, R., and A. J. Ricci. 2003. Adaptation in auditory hair cells. Curr. Opin. Neurobiol. 13: 446-451.

Garvin, J., K. Spring, and P. Santi. 1988. Secretion of endolymph by semicircular canals of the shark. Am. J. Physiol. 255: F711-719.

Ghanem, T. A. 2002. Semicircular canal fluid compartment morphology, ionic composition and regulation in the oyster toadfish, Opsanus tau. Ph.D. dissertation, University of Utah, Salt Lake City.

Ghanem, T. A., R. D. Rabbitt, and P. A. Tresco. 1998. Threedimensional reconstruction of the membranous vestibular labyrinth in the toadfish, Opsanus tau. Hear. Res. 124: 27-43.

Highstein, S. M., R. D. Rabbitt, and R. Boyle. 1996. Determinants of semicircular canal afferent response dynamics in the toadfish, Opsanus tau. J. Neurophysiol. 75: 575-596.

Hudspeth, A. J. 2005. How the ear's works work: mechanoelectrical transduction and amplification by hair cells. C. R. Biol. 328: 155-162.

Ikeda, K., T. Morizono, J. Kusakari, and T. Takasaka. 1988. Magnesium ion activity in the mammalian endolymph measured with ion-selective microelectrodes. Arch Oto-rhino-laryngol. 245: 142-144.

Johnstone, C., R. Schmidt, and B. Johnstone. 1963. Sodium and potassium in vertebrate cochlear endolymph as determined by flame microspectrophotometry. Comp. Biochem. Physiol. 13: 335-341.

Koryta, J. 1972. Theory and applications of ion-selective electrodes. Anal. Chim. Acta 61: 329-411.

Koryta, J. 1977. Theory and applications of ion-selective electrodes. Part II. Anal. Chim. Acta 91: 1-85.

Koryta, J. 1984. Theory and applications of ion-selective electrodes. Part 5. Anal. Chim. Acta 159: 1-46.

Koryta, J. 1986. Theory and applications of ion-selective electrodes. Part 6. Anal. Chim. Acta 183: 1-46.

Koryta, J. 1988. Theory and applications of ion-selective electrodes Part 7. Anal. Chim. Acta 206: 1-48.

Koryta, J. 1990. Theory and applications of ion-selective electrodes. Part 8. Anal. Chim. Acta 233: 1-30.

Maggio, E. 1966a. Danger of perilymph loss during microsurgery of the ear. Considerations based on an experimental study in the cat. Arch. Ital. Otol. Rinol. Laringol. 77: 767-781.

Maggio, E. 1966b. The humoral system of the labyrinth. Acta OtoLaryngol. Suppl. 218: $1+$.

Makimoto, K., and H. Silverstein. 1974. Sodium and potassium concentrations in the endolymph and perilymph of the cat. Ann. Otol. Rhinol. Laryngol. 83: 174-179.

Marcus, D. C., and Z. Shen. 1994. Slowly activating voltage-dependent $\mathrm{K}^{+}$conductance is apical pathway for $\mathrm{K}^{+}$secretion in vestibular dark cells. Am. J. Physiol. 267: C857-864.

Marcus, D. C., M. Rokugo, X. X. Ge, and R. Thalmann. 1983. Response of cochlear potentials to presumed alterations of ionic conductance: endolymphatic perfusion of barium, valinomycin and nystatin. Hear. Res. 12: 17-30. 
Marcus, N. Y., and D. C. Marcus. 1987. Potassium secretion by nonsensory region of gerbil utricle in vitro. Am. J. Physiol. 253: F613-621.

Mayer-Gostan, N., H. Kossmann, A. Watrin, P. Payan, and G. Boeuf. 1997. Distribution of ionocytes in the saccular epithelium of the inner ear of two teleosts (Oncorhynchus mykiss and Scophthalmus maximus). Cell Tissue Res. 289: 53-61.

Ohmori, H. 1985. Mechano-electrical transduction currents in isolated vestibular hair cells of the chick. J. Physiol. 359: 189-217.

O’Neill, M. D., H. M. Wesp, A. F. Mensinger, and R. T. Hanlon. 1998. Initial baseline blood chemistry of the oyster toadfish, Opsanus tau. Biol. Bull. 195: 228-229.

Peterson, S. K. 1978. Element composition of inner ear lymphs in cats, lizards, and skates determined by electron probe microanalysis of liquid samples. J. Comp. Physiol. 126: 1-14.

Rabbitt, R. D., R. Boyle, and S. M. Highstein. 1994. Sensory transduction of head velocity and acceleration in the toadfish horizontal semicircular canal. J. Neurophysiol. 72: 1041-1048.

Rabbitt, R. D., R. Boyle, and S. M. Highstein. 1999. Influence of surgical plugging on horizontal semicircular canal mechanics and afferent response dynamics. J. Neurophysiol. 82: 1033-1053.

Rabbitt, R. D., R. Boyle, G. R. Holstein, and S. M. Highstein. 2005. Hair-cell versus afferent adaptation in the semicircular canals. J. Neurophysiol. 93: 424-436.

Ricci, A. J., and R. Fettiplace. 1998. Calcium permeation of the turtle hair cell mechanotransducer channel and its relation to the composition of endolymph. J. Physiol. 506: 159-173.

Ricci, A. J., Y. C. Wu, and R. Fettiplace. 1998. The endogenous calcium buffer and the time course of transducer adaptation in auditory hair cells. J. Neurosci. 18: 8261-8277.

Ricci, A. J., H. J. Kennedy, A. C. Crawford, and R. Fettiplace. 2005.
The transduction channel filter in auditory hair cells. J. Neurosci. 25: 7831-7839.

Rüsch, A., and U. Thurm. 1989. Cupula displacement, hair bundle deflection, and physiological responses in the transparent semicircular canal of young eel. Pflügers Arch. 413: 533-545.

Salt, A. N., and R. Thalmann. 1988. Cochlear fluid dynamics. Pp. 341-357 in Physiology of the Ear, A. F. Jahn and J. Santos-Sacchi, eds. Raven Press, New York.

Sauer, G., C. P. Richter, and R. Klinke. 1999. Sodium, potassium, chloride and calcium concentrations measured in pigeon perilymph and endolymph. Hear. Res. 129: 1-6.

Silverstein, H., and H. F. Schuknecht. 1966. Biochemical studies of inner ear fluid in man. Changes in otosclerosis, Meniere's disease, and acoustic neuroma. Arch. Otolaryngol. 84: 395-402.

Smith, C. A., O. H. Lowry, and M. L. Wu. 1954. The electrolytes of the labyrinthine fluids. Laryngoscope 64: 141-153.

Steinacker, A. 1996. Ionic current contribution to signal processing by vestibular hair cells. Pp. 204-234 in New Directions in Vestibular Research, S. M. Highstein, J. A. Büttner-Ennever, and B. Cohen, eds. New York Academy of Sciences, New York.

Tasaki, I., and C. Fernandez. 1952. Modifications of cochlear microphonics and action potentials by $\mathrm{KCl}$ solution and by direct currents. J. Neurophysiol. 15: 497.

Thomas, R. C. 1978. Ion-Sensitive Intracellular Microelectrodes. Academic Press, New York.

Wangemann, P. 1995. Comparison of ion transport mechanisms between vestibular dark cells and strial marginal cells. Hear. Res. 90: 149-157.

Wu, Y. C., A. J. Ricci, and R. Fettiplace. 1999. Two components of transducer adaptation in auditory hair cells. J. Neurophysiol. 82: 21712181 